\title{
Commodity Options: A New Risk Management Tool for Agricultural Markets
}

\author{
MICHAEL T. BELONGIA
}

$\mathrm{T}_{\mathrm{r}}$ ities has been banned in the United States since 1936 ities has been banned in the United States since 1936 In a preliminary step to lift this ban, Congress included a provision in the Futures Trading Act of 1982 that atthorized the Commodity Futures Trading Commission (CFTC) to establish pilot programs in the trading of agricultural options. Although actual trading of options on domestically produced agricultural commodities has not yet taken place, the CFTC expects its pilot program to include one option contract at each of the major exchanges. ${ }^{1}$ The pilot programs for agricultural commodities are expected to begin sometime in late 1984 and continue for three years, at which time they will be evaluated.

For many people, the role of options in an overall risk-management strategy is unclear. In fact, because options trading has been banned for many years, the distinguishing characteristics of options are not widely known outside the commodities profession. This article attempts to clarify some of these issues by explaining the basic features of options and drawing distinctions between options and futures. The discussion also includes some simple examples of how options can function as a risk-management tool. Finally, because options contracts contain some - but not all - of the features of agricultural price support programs, the relationship between options markets and price supports is discussed.

\footnotetext{
${ }^{\text {l}}$ Options on sugar are traded currently at the New York Coffee, Sugar and Cocoa Exchange as part of the pilot program's first stage; the options apply, however, only to sugat produced outside of the United States. Options on gold, Treasury bond and stock index futures also are being traded as experimental contracts in the pilot program.
}

\section{FOTWADD CONTRACTS AND TUTUWES CONT}

To define the unique characteristics of a commodity option, it might be useful first to discuss two related concepts: forward contracts and futures contracts. ${ }^{2} \mathrm{~A}$ forward contract typically takes the form of an agreement between a commodity producer and an intermediary agent like the operator of a gram elevator. The contract typically defines an agreement in which a producer agrees to deliver to an elevator owner a specified quantity of grain at a stated date for a set price; the elevator owner agrees to accept delivery of the grain and to pay the set price.

A futures contract is a binding legal agreement between parties to sell or purchase a specified quantity of a standardized commodity at a stated date in the future for a set price. For example, corn contracts at the Chicago Board of Trade are written in 5,000 bushel lots of No. 2 yellow corn and carry stated delivery dates of

\footnotetext{
${ }^{2}$ General references on the role of hedging indude Holbrook Working, "Hedging Reeonsidered," Journal of Farm Economics (November 1953), pp. 544-61; Ronald I. McKinnon, "Futures Markets, Buffer Stocks and Income Stability for Primary Producers," Journal of Political Economy (December 1967), pp. 844-61; and Anne E. Peck, "Hedging and Income Stability: Concepts, Implications, and an Example," American Journal of Agricultural Economics (August 1975), pp. 410-19.

A general overview of trading in commodity options can be found in Avter Wolf, "Fundamentals of Commodity Options on $\mathrm{Fu}$ tures," Journal of Futures Markets (Winter 1982), pp. 391-408; Bruce L. Gardner, "Cormmodity Options for Agriculture," American Journal of Agricultural Economics (December 1977), pp. 986-92; and William 1. Batmol, "Commodity Options: On Their Contribution to The Economy," mimeographed (Princeton, N.J.: Mathematica, Inc., September 1973).
} 
up to 16 months forward. ${ }^{3}$ The set price at which the corn can be bought or sold is determined daily in the market where this particular futures contract is traded.

These definitions indicate at least two respects in which forward and future contracts differ. First, fu* tures are standardized contracts traded in highly liquid and well-organized markets. In contrast, forward contracts are individual agreements between two parties; their unique, case-by-case nature effectively prevents their trading and, consequently, makes them very illiquid. The two contracts also differ in their handling of prices at which exchange will occur. Specifically, the price at which grain will change hands in the forward contract is fixed for the duration of the contract. The price of a futures contract, on the other hand, changes daily as new supply and demand information affects agents' expectations of market prices at the time the futures contract expires. Because forward contracts are not traded in organized markets, they are excluded from the remainder of the discussion. ${ }^{4}$

The price of a corn futures contract depends on expectations of future spot corn prices, and, because these expectations change from day to day, so, too, do contract prices. If a trader believes that corn prices will be above the overall price expected by the market (the average contract price) in the future, he will buy a corn contract for future delivery of 5,000 bushels; this is a "long" position, which will generate an economic profit if the price of corn rises above the contract price. Conversely, an agent who wants to insure against a decline in the expected future price of corn will sell a futures contract agreeing to deliver corn at some future date; this is a "short" position. If the agent is an agricultural producer who holds an inventory of corn, this strategy will provide a hedge against price declines.

We can see, then, why futures markets might exist. ${ }^{5}$ Producers (hedgers) who wish to avoid risk sell a futures contract; although they forfeit the chance to in -

${ }^{3}$ Com contracts are dated for March, May, July, September and December delivery. Contracts typically expire during the second to last week of the stated delivery month.

This is not to say that forward-contracting is umimportant. Instead, unlike futures and options, fonward contracts are individual legal agreements not traded in organized markets.

${ }^{5}$ The question of why futures markets exist does not have a definitive answer. Some economists have argued that these narkets perform an insurance function while others find value in the amount of information on prices and price expectations that futures markets produce; see, for example, Fischer Black, "The Pricing of Commodity Contracts, " Journal of Financial Economics (January March 1976), pp. 167-79

Some economists, however, have questioned the validity of the insurance argument; see, for example, Lester G. Telser "Why There Are Organized Futures Markets,"Joumal of Law and Eco- crease profits if prices increase, they are guaranteed a known return. Other agents (speculators) bear this price risk in return for the chance to profit if prices rise above expectations. As we will see, options function in a similar manner, except for one distinguishing feature of futures contracts: the only way to escape the obligation of the futures contract is to sell it to another party.

\section{WHA}

In contrast, an option conveys the right, but not the obligation, to buy or sell a given amount of a commodity at a fixed price until some specified date when the option expires. Unlike a futures contract, which re quires the purchase or sale of a commodity, the holder of an option may elect to let the option expire without exercising its rights. In this sense, an option is more like a form of price insurance in which one person pays a premium to insure against the possibility of a particular event occurring. If that event - specifically, a large change in price - does not occur, the person who purchased the option loses only the premium he paid for the price insurance. In comparison, losses on short futures positions, essentially, are unlimited; losses on long futures positions are limited to the price of the contract.

The two basic types of options are the "put" and the "call." A call option gives the purchaser of that option the right to purchase a given quantity of a commodity at a stated price on or before the option's expiration date. Conversely, a put option gives the option purchaser the right to sell a given quantity of a commodity at a stated price on or before the expiration date; again, with respect to the CFTC pilot program, options will convey the right to buy or sell a particular futures contract. $^{6}$

nomics (April 1981), pp. 1-23. In particular, Telser contends that a foward contract can provide all of the price insurance offered by a futures contract. Instead, he argues, futures markets exist to meet the demand for a "fungible financial instrument traded in a liquid market" (p. 8). Or, rather, even though forward contracts and futures both provide price insurance, the illiquidity of forward contracts creates a demand for a more liquid instrument that holds the attributes of money (or near money). Futures contracts exist, Telser argizes, to meet this demand for liquidity, not the demand for price insurance.

Finally, some observers have argued that trading in futures is little more than gambling.

${ }^{6}$ The management and surveillance of the pilot program have been simplified by permitting options to apply only to trades of futures contracts. That is, unlike an option to purchase a physical product - a trade that would require agreements on the quality of the product, place of delivery and other contract features - the pilot program will permit only the trading of options on the standardized futures contracts of specific commodities. 


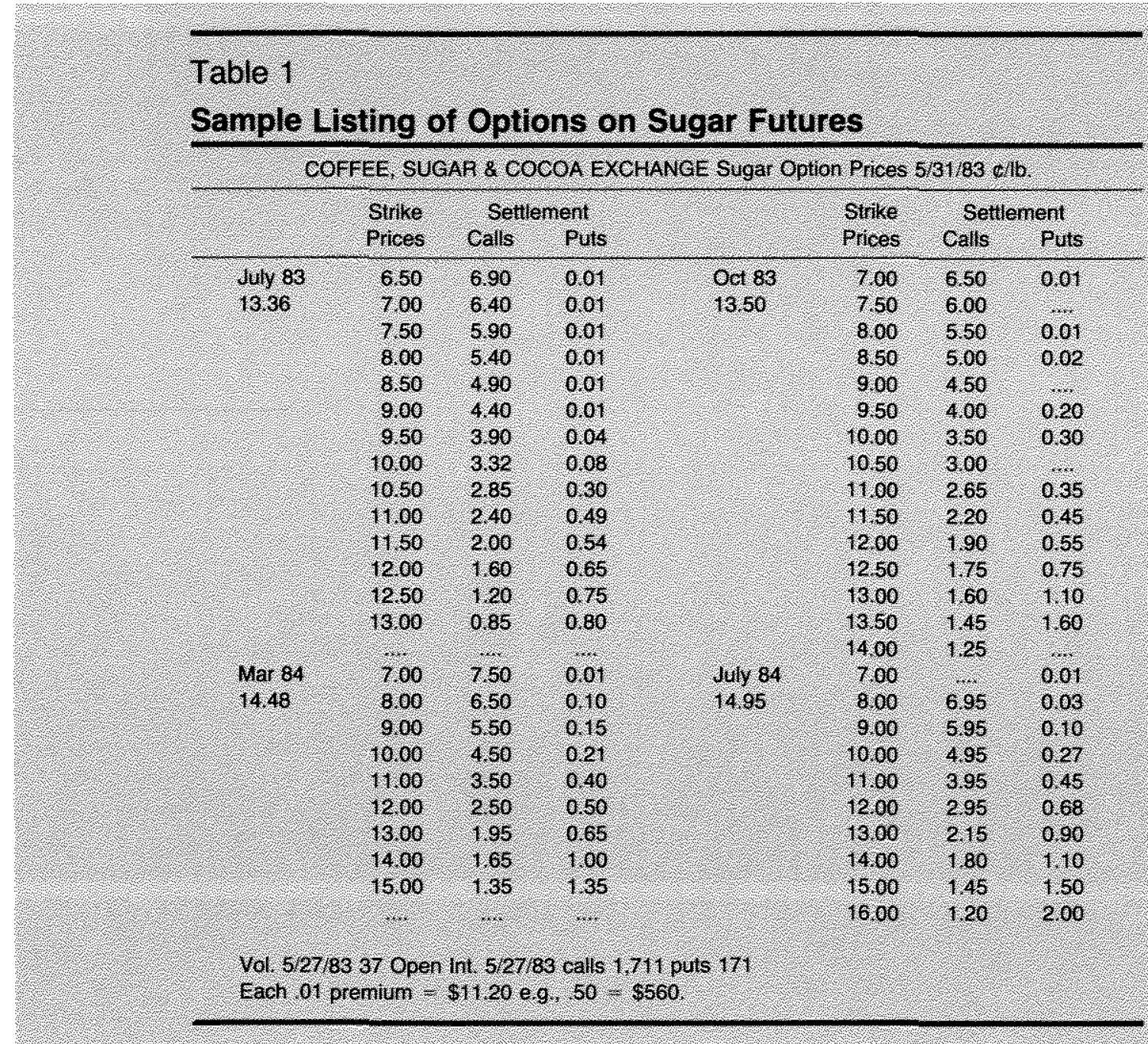

Farmers who wish to use options as a hedge against declining cash prices would buy a put option in combination with positions in the forward, futures or cash markets. Food processors or other businessmen that sought a hedge against price increases in the raw commodities they purchase would buy a call option to complement their positions in other markets. An agent who has a position only in the option market is a speculator. Speculators fulfill a desirable market function by assuming risk that other economic agents do not wish to bear.

Each option contract has several characteristics specified as part of the legal document itself. These include the futures contract to be traded, the price at which the option purchaser may buy or sell the futures contract (called the strike or exercise price) and the expiration date for the option. Another important feature of options - the option premium - is determined by supply and demand conditions in the option market.
The relationships among these different option terms are shown in table 1 , which is a reprint of one daily summary of the sugar options traded on The New York Coffee, Sugar and Cocoa Exchange. The summary, dated May 31, 1983, applies to options on sugar futures that expire in July 1983, October 1983, March 1984 and July 1984 . Considering only the option on July 1983 futures, the summary indicates that strike prices cover a range from 6.5 to 13 cents per pound of sugar; that is, a variety of option contracts are available and each option permits the buyer to sell or purchase sugar futures at a stated price somewhere between 6.5 and 13 cents per pound. The number immediately below the contract date (July 83) is the current price of July sugar futures - 13.36 cents per pound.

The second and third columns, both under the heading "Settlement," are the premiums that apply to the different put and call options contracts. Recall that, while the strike prices of different options are a part of those legal contracts, the settlement premiums on call 
and put options are determined by price expectations in the option market. Generally, premiums are related to three factors: the strike price of the individual option, the length of time until the option expires and the price variability of the underlying futures contract.

To take a specific example from these data, the premium on a call option to purchase July 1983 sugar futures at 10 cents per pound is 3.32 cents per pound; the total cost of guaranteeing the possibility to purchase July sugar futures at 10 cents per pound is 13.32 cents per pound $(10+3.32)$, compared with 13.36 cents per pound futures price. Absent from these cal culations are the transaction costs (brokerage fees) of buying an option or a futures contract.

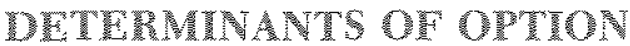 PREMUVMS}

Option premiums are related directly to an option's intrinsic value and its time value. ${ }^{7}$ Intrinsic value is the difference between an option's strike price and the current futures price. For example, if a call option's strike price - the amount at which a corn futures contract could be purchased - were $\$ 2.50$ per bushel and the current futures price were $\$ 2.70$ per bushel, this option would have an intrinsic value of $\$ 0.20$ per bushel. Intuitively, intrinsic value exists if a profit can be made by exercising the rights of the option. If, in the example above, the current futures price were $\$ 2.30$, a call option with a $\$ 2.50$ per bushel strike price would be "out of the money" : that is, a loss would be incurred if the option rights were exercised. Typically, howev-

\footnotetext{
Foption premiums also are infuenced by the volatility of futures prices and interest rates. As futures prices become more volatile, the uncertainty as sociated with any one contract's profitability also increases. This greater uncertainty tends to increase the value of price insurance and, therefore, the value of option preminams. Conversely, high levels of interest rates tend to have negative effects on option values. That is, as the returns on altemative, interest-bearing investments increase, the opportunity cost of holding an option position increases. This "eompetition" among alternative investments will send to decrease option premiums. For a technical discussion of how option premiums are determined, see Fischer Black and Myron Scholes, "The Valuation of Option Contracts and a Test of Market Efficiency, "Journal of Finance (May 1972), pp. 399-418, Black and Scholes, "The Pricing of Options and Corporate Liabilities," Journal of Political Economy (May-June 1973), pp. 637-54. Robert C. Merton, "The Theory of Rational Option Pricing," Bell Journal of Economics and Management Science (Spring 1973), pp. 141-83; Clifford W. Smith, "Op" tion Pricing: A Review," Journal of Financial Economics January/ March 1976), pp. 3-51; James MacBeth and Larry L. Melville, "An Empirical Exanination of the Black-Scholes Call Option Pricing Model," Journal of Finance (December 1979), pp. 1173-86; and Thomas J. O'Brien and William F. Kennedy, "Simultaneous Option and Stock Prices: Another Look at The Black-Scholes Model, The Financial Review (November 1982), pp. 219-27.
}

er, an option's premium will exceed the implied amount of its intrinsic value.

One reason premiums will exceed intrinsic value is a second source of value in an option contract: time value. Because the future is uncertain, there is always the possibility that unexpected events will significantly affect prices. And, because this possibility exists, some market participants will be willing to buy or sell an option on the chance that one such event will occur. This explains, for example, why an "out of the money" option still will be traded at a positive premium; that is, some buyers are willing to take the chance that some event will change futures prices enough to make this a profitable option. Similarly, premiums may be greater than intrinsic value because buyers are willing to pay for the chance that further changes in the futures price may make a profitable option even more profitable before it expires.

An option's expiration date is the key factor in determining its time value. As the length of time until expiration decreases, there is less time for the futures price - and, therefore, the option's profitability - to change markedly. Conversely, an option of long duration has more time value, ceteris paribus, because the probability of an mexpected event changing its profitability is greater.

The concepts of intrinsic value and time value are illustrated by the data shown in table 1. For example, the call option on March 1984 futures with a 14 cents per pound strike price has an intrinsic value of 0.48 cents per pound $(14.48-14.00=0.48)$, which is lower than its premium of 1.65 cents per pound. The 1.17 cent difference between the premium and intrinsic value reflects this option's time value and other factors that tend to increase premiums. Other things being equal, this 1.17 cent difference should decline as the length of time until March decreases and the time value of the option diminishes.

Time value also is shown in the premiums associated with options that apply to futures contracts dated for later delivery. Compare, for example, the four call options with 11 cents per pound strike prices that apply to each of the four listed futures. In this instance - and in others - premiums for options on July 1984 sugar futures are the highest premiums for any of the listed contracts. This occurs because the greater length of time until the option expires increases the probability that some unanticipated event will cause significant changes in futures prices. And, with greater price uncertainty, agents in this market will be willing to pay more for price insurance. 


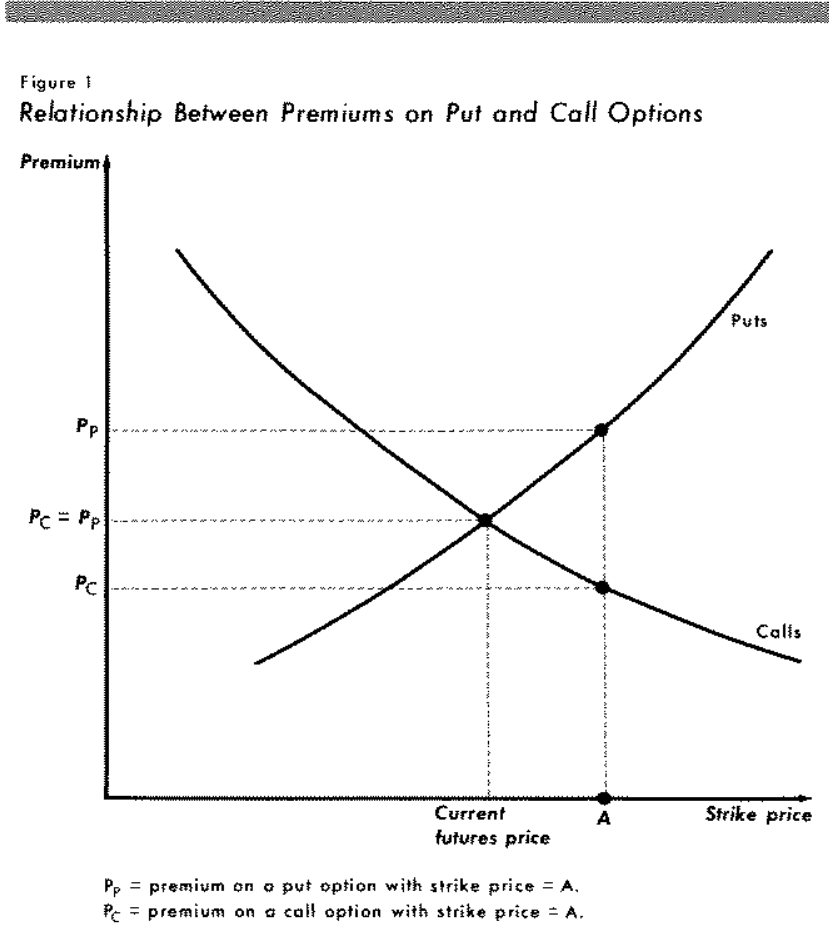

These relationships are illustrated further in figure 1. Strike prices are plotted on the horizontal axis and option premiums are plotted on the vertical axis. The two interior lines labelled "Puts" and "Calls" plot the relationships between strike prices and premiums for the two different kinds of options. In one sense, this figure is a stylized plot of the strike price and premium data contained in table 1 .

As the foregoing discussion suggests, strike prices and premiums for put options should be related positively. That is, the right to sell a product at a low price should have a relatively low value. Conversely, as the strike price at which the product can be sold rises, the right to execute this sale also should increase in value. These relationships are the basis for giving the "Put" line a positive slope.

The strike price-premium tradeoff for call options is just opposite that of puts and, consequently, its line has a negative slope. Intuitively, this is supported by the notion that the right to buy a product at a low price should have a higher value than the right to buy at a high price. Therefore, as a call option's strike price declines, its premium should increase.

The intersection of the "Put" and "Call" lines also suggests a relationship not revealed in the discontinuous data of table 1. Specifically, when an option's strike price is equal to the current futures price, the premium on a put should equal the premium on a call. The reasoning is that, if the futures price represents the market's best guess about actual prices at a later date, the value of the right to buy at that price (a call) should be equal to the value of the right to sell at that price (a put). Or, from a different view, options with strike prices above or below the current futures price carry an implicit bet that the current futures price is "wrong." So, for example, a call option with a strike price at point A would have a relatively low premium, because it would give the right to buy a product in the future at a price higher than the market's current best guess of that future price. Conversely, a put option with that same strike price would have a relatively high premium to reflect the bet that the current futures price underestimates the level of cash prices at the later date.

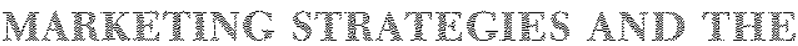 MOLI OE OPETONS}

The mechanics and terminology of options trading may be defined further by way of an example. Consider the case of a farmer who, at time of spring planting, expects to produce 5,000 bushels of corn, an amount that coincides with the size of one futures contract. He also thinks that his total cost of producing each bushel of corn will be $\$ 2.50$. Finally, he knows that the futures contract dated for December delivery - - after his harvest time - values corn at $\$ 2.80$ per bushel. Assuming a constant 10-cents-per-bushel basis, he can expect local cash prices at the time of harvest to be $\$ 2.70$ per bushel. $^{8}$

These prices and the effective support prices of government crop programs represent the core of information on which his marketing decisions must be made. Still unknown, however, are the quality of the growing season weather and the effects it and other factors may have on his yield per acre. Or, rather, because he still is unsure of his yields and those of other producers, it is unclear whether cash prices at harvest will be higher or lower than $\$ 2.70$.

\footnotetext{
${ }^{8}$ Basis is the per unit difference in the futures price and the local spot (cash) price for a commodity. In this example, the current (May) price of a December futures is $\$ 2.80$; the current spot price is $\$ 2.70$. Therefore, the basis is $\$ 0.10$. The returns to a person with a position in the fitures market is the change in the basis that occurs. That is, if December futures increase to $\$ 3.00$, the basis becomes $\$ 0.30(\$ 3.00-\$ 2.70)$ which produces a $\$ 0.20(\$ 0.30-\$ 0.10)$ change in the basis. This 20-cent change will be a gain or loss depending upon whether a person held a long or short position in futures. Typically, the basis reflects the spread between local spot markets and the relevant futures market. Costs of financing, storage and insurance also are part of the basis. Also, contrary to the simplifying assumption of this example, the basis will not be constant during the crop year.
} 
Table 2

Results of Alternative Marketing Strategies Under a Price Increase

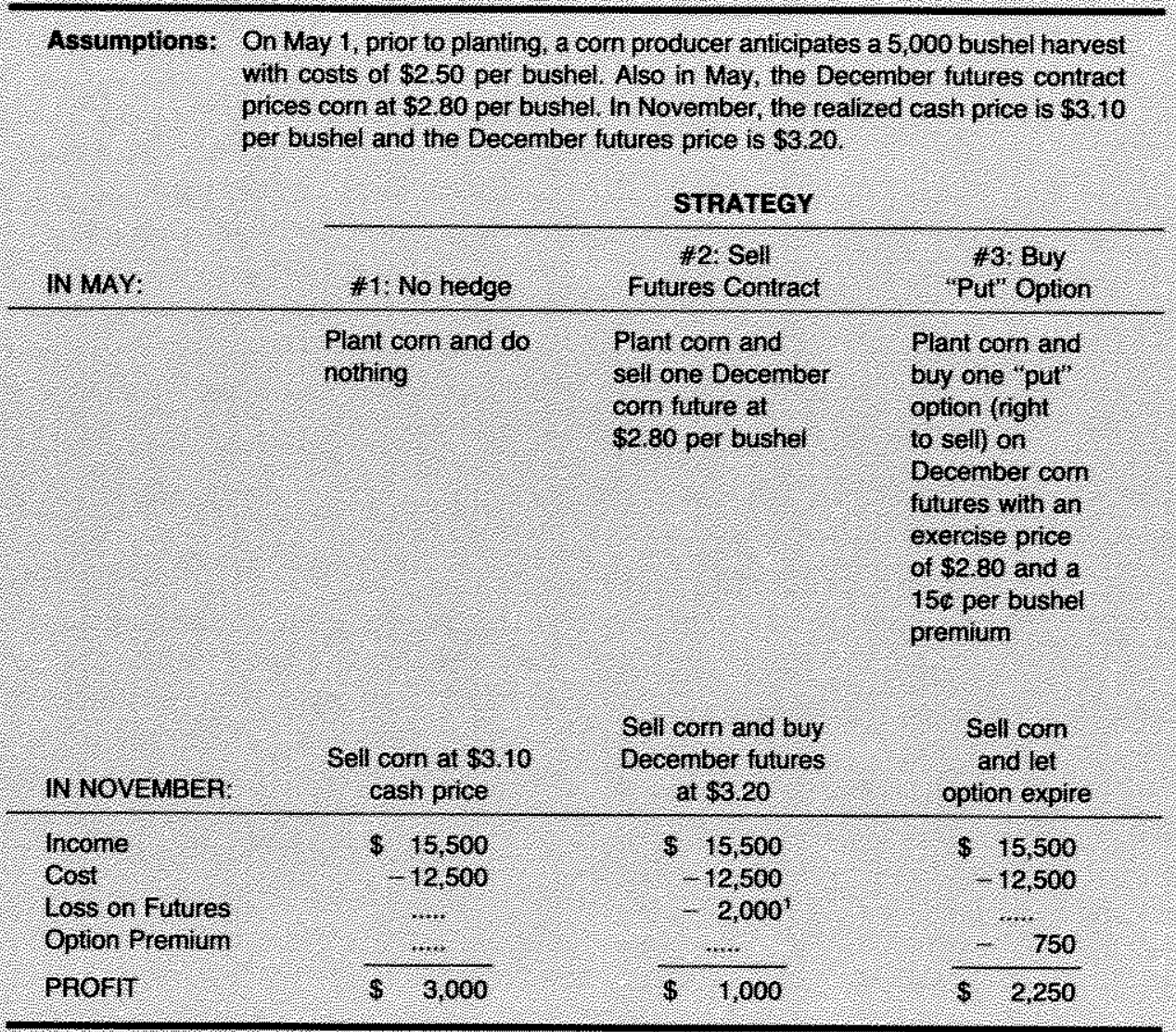

TThe ncrease in the price of Decenber tutures from $\$ 2.80$ lo $\$ 3.20 \mathrm{~m}$ plies a 50.40 per bushel loss to the person who sold December tutures in May.

Depending on his own attitude toward risk, an individual producer may choose several marketing strategies. On one extreme, he may go totally unhedged - that is, he may just harvest his crop and accept whatever cash price prevails at that time. At the other extreme, a very risk-averse producer may hedge his entire crop by selling one corn futures contract. By hedging, the producer can guarantee that the price he receives for his corn will be $\$ 2.80$ per bushel, the current price of December corn futures. Between these extremes is a strategy in which a portion of the crop is hedged in the futures market and the remainder is sold at the prevailing cash price.

These strategies, however, also indicate that there is a gap in alternatives that would be filled by a market in commodity options. That is, a producer who is totally unhedged has no insurance against downside price movements. Or, following this example, a producer who does not hedge at least part of his crop in the futures market might face a cash price of something like $\$ 2.00$ at time of harvest if the national crop is larger than previously expected; this would produce a loss of $\$ 0.50$ per bushel. Conversely, a producer who hedged all 5,000 bushels at $\$ 2.80$ has no alternative but to accept that price at harvest. While this form of price insurance guarantees $\$ 2.80$ per bushel, it also precludes the chance to sell for the higher cash prices that could prevail if the national crop were smaller than expected. Instead of these marketing positions, a more flexible approach would have two characteristics: it would provide insurance against a decline in cash prices, while simultaneously allowing gains to be made if cash prices increased above contract prices. Commodity options have these features. ${ }^{9}$

\footnotetext{
${ }^{9}$ Options have the advantage that if a farmer's hedge became uncovered due to, say, a crop failure, his losses would be limited to the option premitm. Losses from a futures hedge under these conditions could be much larger if prices increased substantially.
} 
Continuing with the earlier example, it is clear that a market in commodity options would expand the scope of marketing strategies for farmers and agribusiness. In addition to the earlier marketing strategies - no hedging versus complete hedging - a third strategy involving an option is introduced. Under the assumptions in this example, production costs of $\$ 12,500$ will be incurred under any marketing strategy $(5,000$ bushels $x$ $\$ 2.50$ per bushel). Also assumed is a $\$ 750$ (15 centsper-bushel premium) cost for buying a "put" option.

Table 2 shows the results of these strategies under an assumed increase in futures prices to $\$ 3.20$ per bushel; assuming a constant 10-cents basis throughout this example, cash prices at harvest would be $\$ 3.10$ per bushel. ${ }^{10}$ Each strategy is detailed in a separate column of the table. Each strategy also involves two distinct steps: first, the choice of a marketing strategy at time of planting (May) and, second, the execution of that strategy after harvest (November). These stages are represented in the upper and lower halves of the table. 11

Under assumed increases in futures prices to $\$ 3.20$ and in cash prices to $\$ 3.10$ per bushel, strategy No. 1 yields a return of $\$ 3,000$, the highest of the three strategies. Because income and production costs are equal in each strategy, the "no hedge" earns greater returns because it avoids a loss of futures (strategy No, 2) and the cost of option premiums (strategy No. 3). Therefore, a producer choosing strategy No. 1 earned a greater profit during this year but did so without insurance against price declines. Conversely, producers choosing to hedge their crops or purchase options realized smaller profits, but were protected against the possibility of price decreases. The return to strategy No. 2 is lower by the $\$ 2,000$ loss on the sale of December futures $[(\$ 3.20-\$ 2.80) \times 5,000 \mathrm{bu} .=\$ 2,000]$. Producers choosing to buy options instead of futures earned greater profits, but this result is dependent on the assumed values for alternative options premiums

\footnotetext{
${ }^{10}$ Each of these examples ignores a number of factors that would complicate the analysis. For example, the output of this individual producer does not vary with changes in aggregate production. The retums also are dependent on assumptions regarding the elasticity of demand. Rather than providing a complete analysis that considers these complicating considerations, however, the intent of the examples is to illustrate qualitative differences among the various strategies.

${ }^{11}$ The strategies shown are the most basic approaches to grain marketing. Much more complicated examples, which combine the simultaneous ase of differing positions in futures and options markets, can be ased to illustrate how varying levels of price insurance and speculation can be achieved. See, for instance, the strategies discussed in Strategies for Buying and Writing Options on Treasury Bond Futures pablished by the Chicago Board of Trade. These examples cal be adapted with few changes to strategies for grain marketing.
}

and changes in futures prices; these results merely illustrate qualitative differences among marketing strategies.

Returns under different risk-management strategies might be illustrated more clearly by re-evaluating the previous example under a decline in the futures price. Table 3, which includes balance sheet figures for an assumed November futures price of $\$ 2.40$ and cash price of $\$ 2.30$ (constant 10-cents-basis assumption), reports these results. As in the previous example, the strategy involving options (No. 3) yields a return between those of the other strategies. Now, however, after a price decline, the unhedged strategy (No. 1) yields a loss of $\$ 1,000$; or, rather, column one shows what can occur if market prices decline and a producer has no protection against such losses. Conversely, column two - under a strategy of complete hedging shows the benefits of locking in a known price at the time of planting. Finally, the strategy that includes options shows a profit, but one less than that for selling futures; the difference is the amount of the option premium. But, although the premium costs are $\$ 750$, the purchase of the corn futures yields a return of $\$ 2,000$.

Finally, table 4 illustrates the relative returns to the three strategies if prices do not show a net change during the year. As the entries in the table indicate, each strategy would result in a sale of corn in the cash market at $\$ 2.70$ per bushel. Once again ignoring the transaction costs of futures or options contracts, strategies No. 1 and No. 2 would yield a profit of $\$ 1,000$, whereas the cost of the option premium would reduce returns to strategy No. 3 to $\$ 250$.

In view of these differing returns to different strategies as assumptions vary concerning end-ofseason prices, an important consideration is the expected (ex ante) return to each marketing strategy. That is, in May, what can an individual producer expect to earn from crop marketings in November? A comparison of these expected values is shown in table 5 .

As the table indicates - for this set of alternative outcomes and probabilities - strategies No. 1 and No. 2 yield equal expected returns, while the strategy using options produces a lower expected return. This is not unlikely, however, in view of the speculative services that options offer in addition to their basic price insurance. ${ }^{12} \mathrm{Or}$, rather, because options offer a chance

\footnotetext{
${ }^{12}$ For example, see Telser, "Why There Are Organized Futures Markets," for a discussion and references concerning why agents may choose to engage in speculative strategies in which expected returns are negative.
} 


\section{Table 3}

\section{Results of Alternative Marketing Strategies Under a Price Decrease}

\begin{tabular}{|c|c|c|c|}
\hline \multirow{2}{*}{ W } & \multicolumn{3}{|c|}{ STFAHECY } \\
\hline & 41 No hedge & $\begin{array}{l}\text { \#2. Sell } \\
\text { Futures Contrad }\end{array}$ & $\begin{array}{l}\text { Por Buy } \\
\text { Opution }\end{array}$ \\
\hline
\end{tabular}

Same strategy as in table?

l.
.

Trotal hoome of $\$ 13,500$ is derved fron sales of harvested com $(5,000$ bu. $x(\$ 2,30-\$ 11,500)$ and

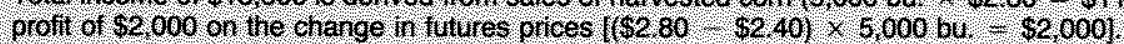

\section{Table 4}

\section{Results of Alternative Marketing Strategies Under Constant Prices}

\begin{tabular}{|c|c|c|c|}
\hline & & STRATEGY & \\
\hline novir & (. 1. Wo hedge & furtures contract & 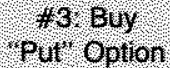 \\
\hline
\end{tabular}

Same strategy as in lable?

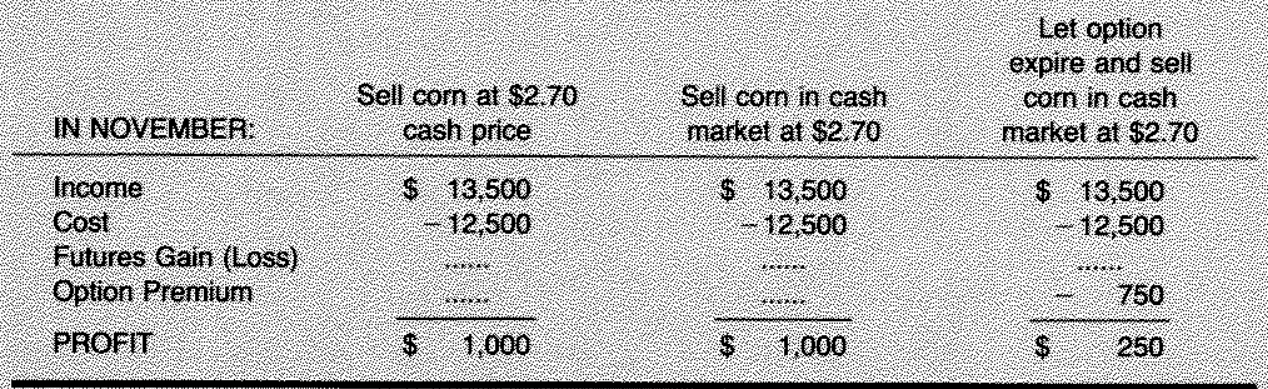




\section{Table 5 \\ Expected Retums From Alternative Marketing Strategles}

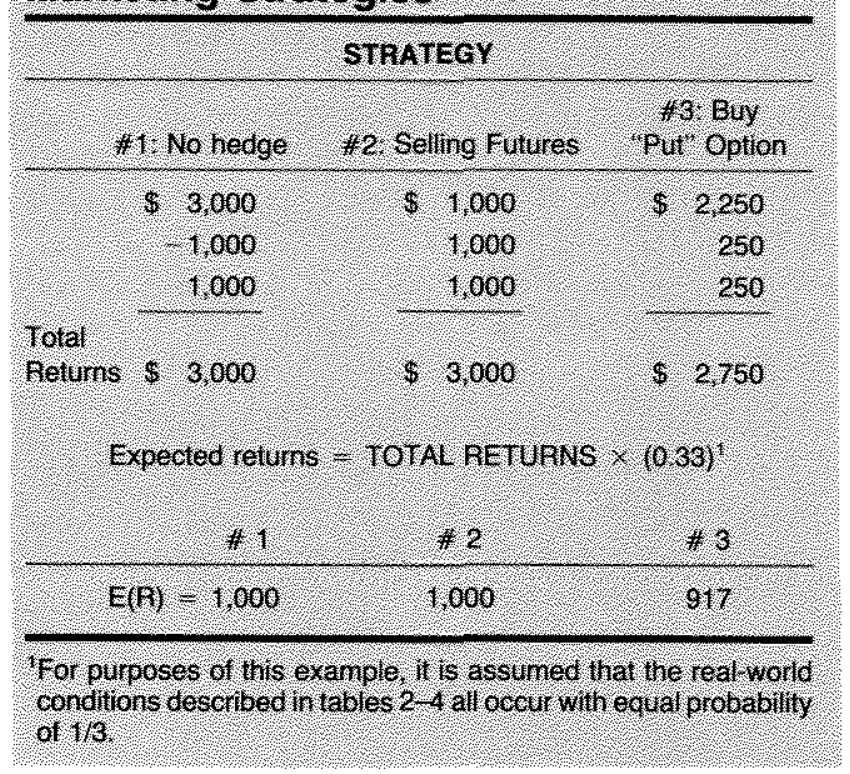

for additional profits if prices rise to a level greater than the sum of the market price plus the option premium, it is expected that this additional speculative feature can be gained only at some additional cost.

These relationships might be seen more clearly in a graphic comparison of returns produced by the three marketing strategies discussed earlier. Figure 2 plots returns for unhedged (1), straight-hedge (2) and options (3) strategies. ${ }^{13}$ The dashed line shows the returns to an unhedged strategy in which all grain is sold in the cash market at the prevailing price; as might be expected, it is a 45-degree line from the origin. Returns to a straight hedge, involving the sale of a futures contract, are shown by the horizontal line drawn at a level denoted by $R_{\mathrm{F}}$. This line shows that the producer can guarantee a return of $R_{\mathrm{H}}$ per bushel but cannot gain from price increases above that level.

The kinked line shows the returns to a strategy involving options and, by inference, the role options play in hedging - speculative strategies. In fact, the shape of this returns line illustrates the unique features of a put option. The horizontal segment of the line, drawn at a level equal to $\$ 2$, shows the maximum return that can be achieved if futures prices are below the option's exercise price. Or, rather, because the

\footnotetext{
${ }^{13}$ This figure is adapted from a similar diagram in Gardner, "Commodity Options for Agriculture."
}

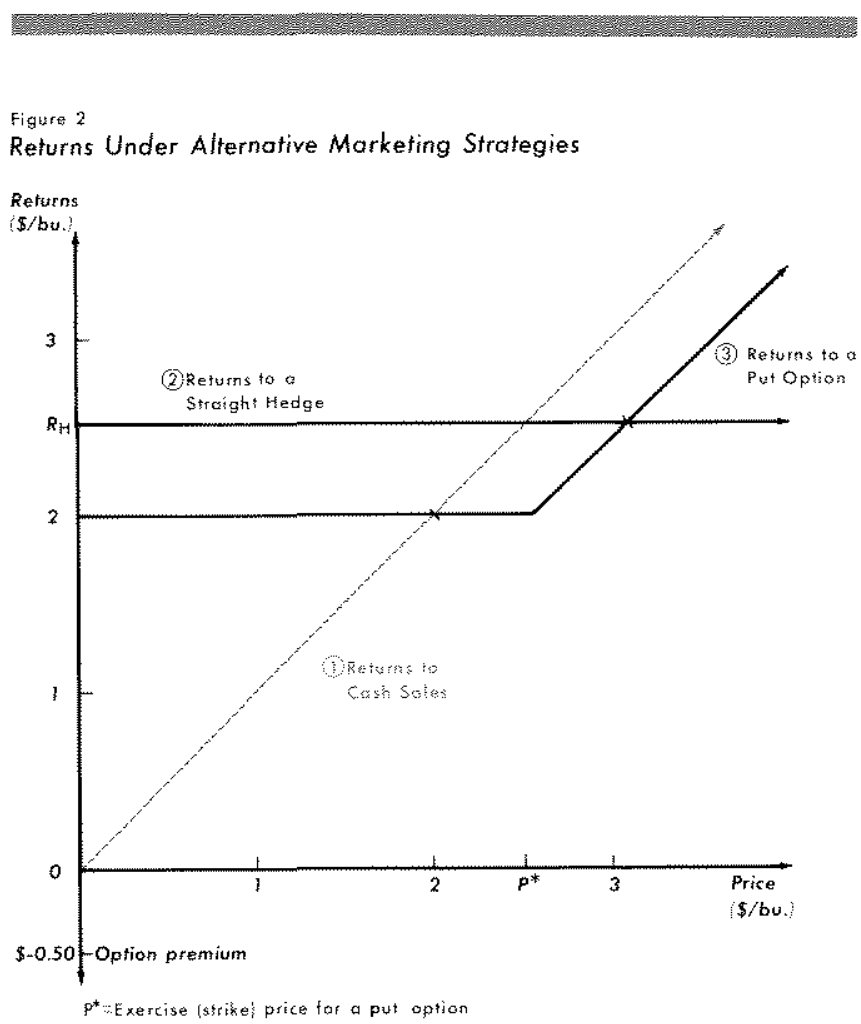

figure indicates that the option premium is $\$ 0.50$, the $\$ 2$ level of the net returns line implies that the option's strike price is $\$ 2.50$ (strike price - premium = net return). This horizontal line segment also is the minimum return the owner of this put option will earn. The horizontal portion of the option's return line, then, represents the insurance characteristics of an option.

The returns line also has an upward-sloping segment that begins at the break-even price of $\$ 2.50$; this segment illustrates the speculative characteristics of options. That is, for futures prices above $\$ 2.50$, the option can be allowed to expire, and the grain can be sold in the cash market at higher prices. Notice, however, that this portion of the option's return line falls below the "returns to cash sales" line by an amount equal to the option premium. Conversely, at all prices above $\$ 3.00$, the option yields a higher return than a straight hedge in the futures market.

Finally, it should be noted that figure 2 implies that a strategy involving options performs most poorly if prices remain within a $\$ 2.00-\$ 3.00$ band; both futures and cash market sales will produce a higher net return for prices in this range. And, because the current futures price in this example is $\$ 2.50$, this result high lights again the unique feature of an option: it carries the implicit "bet" that the futures price underesti- 
mates the eventual level of cash prices by a substantial margin. In fact, as this example is written, the purchaser of a call option on this futures contract would believe the futures price will increase by at least 20 percent (50 cents) to offset the option's 50-cent premium.

The general result implied by these examples is that commodity options provide insurance against price declines without totally eliminating the potential profits from price increases. Although total returns to a strategy involving options tend to be lower than returns to other strategies (for example, strategy No. 1 in table 2 and strategy No. 2 in table 3) because the additional costs of option premiums are incurred, options never produce a loss (in these examples) and yield substantially higher returns than futures if prices increase. Therefore, somewhat lower average returns provided by a strategy involving options might be viewed as the price paid for additional speculative services not available in futures markets.

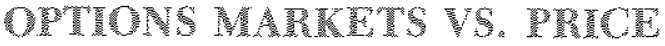 SUPPORTS}

A market in commodity options would offer grain producers many of the hedging opportunities currently available in legislated price support programs. ${ }^{14}$ For example, a put option's strike price would function in much the same manner as program loan rates. And, as with an option position, a producer is not required to comply with program provisions but may elect to exercise program privileges at his discretion. At a general level, options and price support programs function in similar fashion. And, in one sense, a function of the CFTC pilot program may be to discover whether options markets can co-exist with price support programs as they now stand.

There are at least two important differences, however, between options and current price support programs. First, unlike one specified loan rate that applies for an entire crop year, an option purchaser may select from a variety of contracts with different strike prices and premiums. Second, trading in options contracts will not have the large and direct effects on agricultural production and resource allocation that have been attributed to price supports. The particulars of each distinction are discussed below.

If a grain producer is eligible to participate in a price support program, one of his key decision variables is

\footnotetext{
${ }^{14}$ For a discassion of these programs, see Michael T. Belongia, "Outlook for Agriculture in 1983," this Reciew (February 1983), pp. 14-24; or Bruce L. Gardner, The Governing of Agriculture, (The Regents Press of Kansas, Lawrence, Kansas, 1981).
}

the program's loan rate. If market prices fall below the loan rate, which is a legislatively determined price per bushel of grain, the producer can place his grain in Commodity Credit Corporation (CCC) stocks and receive a loan in exchange; the loan value is determined by multiplying the number of bushels placed in CCC stocks by the loan rate. If, after nine months, market prices have not risen above the loan rate, the producer may elect to forfeit his grain to the CCC and keep the loan. In this way, the loan rate serves as an effective price floor for eligible producers. Also notice that, although these producers are hedged against price declines, they are free to sell their grain at market prices if such prices rise above the loan rate.

This protection against large price declines, while maintaining the possibility of profits, also is a distinguishing feature of a commodity option. Options, however, differ from government price supports by offering a range of strike prices (essentially, different loan rates) from which a producer can choose. In other words, options allow producers to select the level of prices at which they wish to be hedged against further price declines.

This point can be clarified by an example. Consider, for instance, the 1983 corn program and its loan rate of $\$ 2.65$ per bushel. While it provides this price floor for producers, price insurance against declines below, say $\$ 2.90$, is available only by selling a futures contract at that price. Recall, however, that one disadvantage of this strategy is the rigidity of obligations implied by a futures contract.

In contrast to these less flexible strategies, a viable options market would allow producers to select the level of price insurance they desire. For example, as a parallel to the data in table 1 , an option on corn futures might list strike prices ranging from $\$ 2.30$ to $\$ 3.20$ per bushel; each option also would have its own premium. Therefore, a producer who wanted protection against price declines below $\$ 3.20$ could buy a put option with that strike price. Similarly, if $\$ 2.30$ were an acceptable price floor, that put option could be purchased. The unique feature of options, however, is that individuals are free to select the amount of price insurance they desire and pay a competitively determined premium for it.

The other main distinction between options and price supports is that options are not likely to have large direct effects on the quantity of grain produced. ${ }^{15}$ Economic theory suggests that effective support pro-

\footnotetext{
${ }^{15}$ See Gardner, "Commodity Options for Agriculture."
} 
grams will increase production by increasing producers' expected prices and decreasing the variance of their returns. ${ }^{16}$ Under these conditions, producers can expect to receive greater returns at less risk. If program incentives to increase production are not offset by output reductions effected by program acreage limitations, price supports will allocate too many resources to the production of the protected commodities. These distortions in resource allocation could be avoided if they were replaced by options trading.

But even if direct effects on output were minimized, options will not avoid all resource allocation effects associated with government price support programs. For instance, this approach to risk management may induce some producers to shift from the use of fertilizer and pesticides to the purchase of options. Similarly, agents who write options will likely shift some resources from other investments to the purchase of futures or physical commodities in an effort to offset their options positions. Therefore, to the extent options become an attractive asset to marketing strategies, this new market will have some effects on resource allocations.

What options would avoid are the wealth transfers and capitalization effects associated with the "free" price insurance of government programs. ${ }^{17}$ That is, current government programs transfer wealth from taxpayers who pay for the price insurance to producers

\footnotetext{
${ }^{86}$ See, for example, Michael T. Belongia, "Agricultural Price Supports and Cost of Production: Comment," American Journal of Agricultural Economics (August 1983), forthooming.

${ }^{77}$ Producers do pay - indirectly - if they are required to reduce output to participate in the price support programs.
}

who receive the benefits of its protection. Wealth also is transferred from land buyers to land owners via the capitalization of program benefits into the value of land eligible for those benefits. This capitalization also raises land prices above the level they would have been in the absence of government programs. This induced change in land prices then affects the mix of resources used to produce products in which land is an input. Other secondary effects on resource allocation also could be avoided if government programs were replaced by options markets.

\section{CONCWUIONS}

The trading of options on agricultural commodities is likely to begin sometime in 1984 under a pilot program supervised by the CFTC. Options fill a gap between futures markets and the price insurance of government programs by offering market participants the opportunity to select the amount of price insurance they desire while, simultaneously, not precluding the opportunity for profits if prices change appreciably.

Although options will never provide the highest level of income that could have been earned under an assumption of perfect foresight, marketing strategies that include options establish a minimum price for producers without eliminating the opportunity for gains if market prices increase. Finally, although options and price support programs are alike in many respects, options would provide greater flexibility in choosing a level of price insurance. Further, they are less likely to increase agricultural production or produce the distortions in resource allocation associated with price support programs.

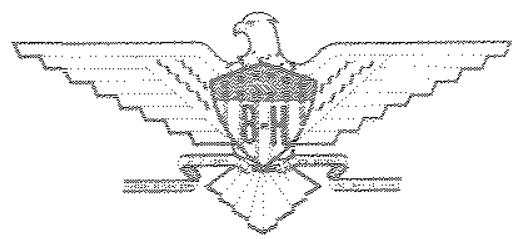

